\title{
AN INVESTIGATION INTO POST-GRADUATE PHYSIOTHERAPY EDUCATION IN SOUTH AFRICA
}

\section{S H Irwin-Carruthers ${ }^{\star}$}

\begin{abstract}
SUMMARY
This article outlines the development of post-graduate physiotherapy education in South Atrica and the problems encountered. The method and results of two surveys are discussed. The first, conducted in 1986, ascertained involvement and interest in post-graduate study, and the reasons for non-participation. The respondents' needs and preferences were also analysed. The second (1989) survey investigated the extent to which universities were meeting these needs.

The difference between clinical specialisation and academic post-graduate study is discussed and the progress made in the former is detailed.

Proposals are made for overcoming current problems in postgraduate programmes, including delineating objectives and competencies, optimum management of existing resources and developing new resources. The question remains as to whether the direction in which post-graduate programmes are developing at present can be justified in terms of the needs of the population.
\end{abstract}

Post-graduate physiotherapy education in South Africa is still in its infancy. Of the eight physiotherapy training courses offered in South Africa, the first to offer a degree course was the University of the Witwatersrand. Only two universities, those of Stellenbosch and the Western Cape, offered degree courses from their inception. Although the first BSc Physiotherapy degrees were awarded in the late nineteen-forties, the first post-graduate degree was only awarded nearly forty years later. Again it was the University of the Witwatersrand which took the lead.

In 1985 the South African Society of Physiotherapy adopted, for the first time, a set of long-term objectives. These included a section on post-graduate education. The goals set then were:

To encourage the acquisition of higher degrees by members of the profession

- to investigate existing post-graduate programmes

- to publish details of existing programmes

- to investigate sources of financial assistance

- to investigate the possibility of making the possession of postgraduate qualifications a prerequisite for higher-level and university appointments

- to delineate objectives and competencies for post-graduate study at masters, honours and post-graduate diploma level

- to set up guidelines for the development of future post-graduate programmes.

Why is post-graduate education necessary? The reasons advanced included professional self-achievement and advancement, refinement of research skills in order to give the profession credibility, and assurance of professional status. This last reason includes the necessity to conform with norms laid down by the Department of National Education. There are, however, more pressing reasons for South Africa, where we are looking towards providing health for all with diminishing economic resources.

Although the move to provide post-graduate degree courses

\section{OPSOMMING}

Die artikel skets die ontwikkeling van nagraadse fisioterapie-opleiding in Suid Afrika asook die probleme wat bestaan. Die metode en resultate van twee opnames word bespreek. Die eerste opname, wat in 1986 onderneem is, het belangstelling en deelname in nagraadse studie ondersoek, asook die redes vir gebrek aan deelname. Die behoeftes en voorkeure van die steekproef is ook vasgestel. Die tweede opname (in 1989) het die mate waarin universiteite aan hierdie behoeftes voldoen, ondersoek.

Die verskil tussen kliniese spesialisasie en nagraadse studie word bespreek, asook die huidige stand van eersgenoemde.

Voorstelle om die huidige struikelblokke met betrekking tot nagraadse programme te bowe to kom sluit in die bepaling van doelwitte en bevoegdhede, die optimale benutting van huidige bronne en die ontwikkeling van nuwe bronne. Daar word nog bevraagteken of die huidige rigting van ontwikkeling van nagraadse programme eintlik aan die behoeftes van die bevolking voldoen.

started more than 20 years ago, relatively few degrees have been awarded so far - three doctorates, a dozen or so masters degrees and even fewer honours degrees. Why is this? To try to answer this question a survey was conducted in 1986 to establish the extent of interest in post-graduate education.

The ten branches of the South African Society of Physiotherapy were asked to distribute survey forms to their members, and it is not known how many of the Branches complied, nor how many forms were distributed. 399 replies were received, representing approximately $30 \%$ of the membership at that time. The characteristics of the respondents are given in Table 1 (page 5).

It is interesting that several subsequent surveys have confirmed that only $27 \%$ or less of registered physiotherapists work in state or provincial institutions.

Although just over $60 \%$ of respondents held a basic degree in physiotherapy, only $25(6 \%)$ held a post-graduate degree in physiotherapy. A further 25 held a post-graduate physiotherapy diploma (mainly in tertiary education), whilst 35 held nonphysiotherapy post-graduate degrees, mainly in psychology, other humanities and theology. Apart from education, the most popular fields for post-graduate study were paediatric neurology and/or cerebral palsy, and sports medicine. (Neurodevelopmental therapy and manipulative therapy predominated in continuing education courses, with $49 \%$ each).

Despite the very few physiotherapists who had undertaken post-graduate study, 309 (77\%) of respondents indicated that they would like to do so. Why then the very low participation rate? Only $45 \%$ of respondents commented, some giving multiple reasons. The main factors cited were lack of material recognition (30\%), family commitments, advanced age (the oldest respondent was 89 years of age!), poor quality of existing courses, lack of viable physiotherapy research units, work commitments, geographical location and laziness. On the incentive side, respondents indicated an increasing 

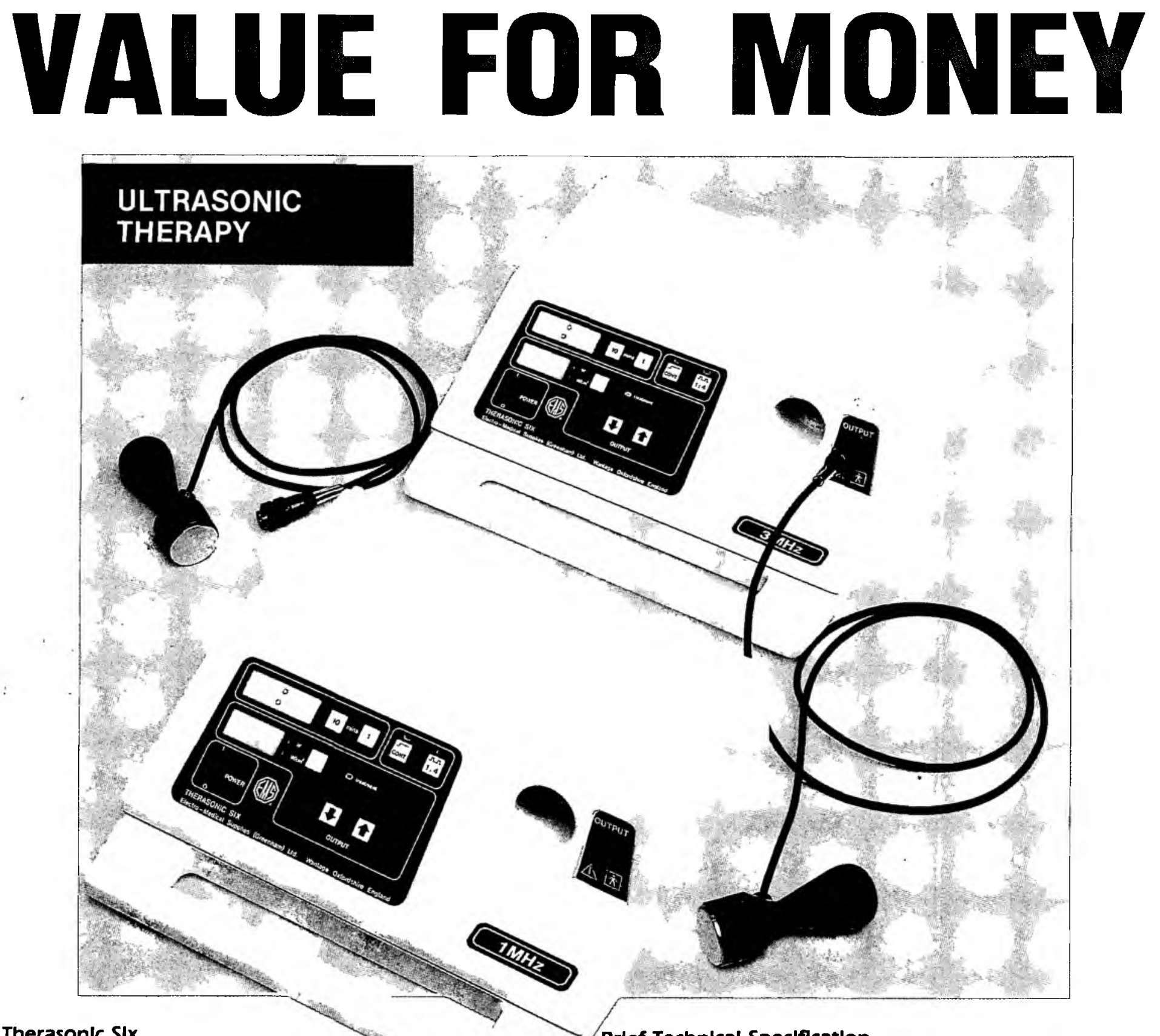

\section{Therasonic SIx}

The Therasonıc Six is the latest application by EMS of new technology to produce a single output, single frequency ultrasonic therapy unit.

The Six incorporates many of the features of the more sophisticated 1032 unit - the same case, the same design of treatment head, the same superb-quality push button type of control panel; also the same waterproof carrying case (as an optional extra).

It is available in two versions - a $1 \mathrm{MHz}$ model and a 3

$\mathrm{MHz}$ model. Both models are identical in everything except the operating frequency.

The Therasonic Six weighs only $4.2 \mathrm{~kg}(9 \mathrm{lb})$

Facilities include:

1.7 output levels - 0.1, 0.2, 0.5,0.75, 1.0.1.5, $2.5 \mathrm{w} / \mathrm{cm}^{2}$

2. Pulsed and continuous modes.

3. Digital treatment timer.

4. Fully-immersible $5 \mathrm{sq} \mathrm{cm}$ treatment head (protected by automatıc cut-out when not in patient contact).

5. Socket fitted to unit to allow for combination therapy (ı.e. ultrasound with interferential, diadynamic, faradic).

Brief Technical Speclfication

Therasonlc SIx - $1 \mathrm{MHz}$ Model and $3 \mathrm{MHz}$ Model

Power input

Power consumption

Size

Weight

Classification

Frequency

Output

Pulse Duration

Pulse on/off ratio

Max. Output Intensity

Output Intensity Settings $0,0.1,0.2,0.5,0.75,1.0,1.5,2.5$

Max. Output Power

Output Power Settings
$100,120,220,240 \mathrm{~V} \sim 50 / 60 \mathrm{~Hz}$

$45 \mathrm{~W}$

$320 \times 302 \times 110 \mathrm{~mm}$

$4.2 \mathrm{~kg}$

Class 1: Type BF (IEC 601-1: 1977)

1.1 $\mathrm{MHz}+/-5 \%$

(3 $\mathrm{MHz}$ Model - $3.4 \mathrm{MHz}+/-5 \%$ ) Both continuous and pulsed $2 \mathrm{~ms}$

$1: 4$

25 Watts per squar Watts per square $\mathrm{cm}$ $11.4 \mathrm{~W}$

(3 MHz Model - 9.7 W)

$0.0 .4,0.9,2.2,3.3,4.5,6.7,11.2 \mathrm{~W}$ (3 MHz Model - 0, 0.4, 0.8, 2.0, 2.9, 3.9, 5.9, 9.7 (W)

\section{FOR FULL DETAILS CONTACT}

MEDICAL DISTRIBUTORS

P O Box 3378 Johannesburg 2000 Phone: (011) 29-6931 
desire to specialise, the need to keep up with rapid advances in medical science, the desire to improve the image of the profession and a commitment to service to the community.

\section{SURVEY ON POST-GRADUATE EDUCATION}

$\begin{array}{lrr}\text { QUALIFICATIONS } & \mathrm{n} & \% \\ \text { 3 year diploma } & 156 & 39 \\ 4 \text { year degree } & \mathbf{2 4 3} & \mathbf{6 1} \\ & 399 & 100 \\ \text { Post-graduate degree } & 25 & 6 \\ \text { Post-graduate diploma } & 25 & 6 \\ \text { Non-P T degree/diploma } & \underline{35} & \frac{9}{21} \\ & 85 & \\ \text { DISTRIBUTION } & 108 & 27 \\ \text { Public sector } & 215 & 54 \\ \text { Private sector } & 27 & 7 \\ \text { University } & 49 & 12 \\ \text { Not working as P T } & 399 & 100 \\ & & \\ \text { EMPLOYMENT } & 299 & 75 \\ \text { Full-time employment } & 51 & 13 \\ \text { Part-time employment } & 49 & 12 \\ \text { Not working as P T } & 399 & 100\end{array}$

TABLE 1: CHARACTERISTICS OF RESPONDENTS TO 1986 SURVEY

TABLE 2: PREFERENCES IN POST-GRADUATE STUDY

\begin{tabular}{lrlr}
\hline TYPE & $\%$ & \multicolumn{1}{c}{ FORM } & $\%$ \\
Part-time/highly structured & 61 & Coursework only & 48 \\
Part-time/loosely structureg & 31 & Coursework and thesis & 47 \\
Full-time/highly structured & 6 & Thesis only & 5 \\
Full-time/loosely structured & $\frac{2}{100}$ & & 100
\end{tabular}

Table 2 details the form of post-graduate study which the respondents preferred, reflecting a strong inclination towards parttime study and a highly structured format. This is probably a reflection of the economic pressures of the last five years (including the very poor salary structure for physiotherapists in the public sector) as well as the relative inexperience of South African physiotherapists in research methodology and implementation.

Increasing pressure from the Manipulative Therapists' Group for the right to call themselves specialists led the South African Society of Physiotherapy to re-assess their objectives in 1987. The objectives for post-graduate education were amended to include establishing a process for clinical specialisation, in addition to the still outstanding objectives of delineating objectives and competencies for post-graduate study and setting up guidelines for the development of future post-graduate programmes.

How close are we to achieving any of these objectives? First of all we must differentiate between clinical specialisation and postgraduate education. Clinical specialisation is the process of acquiring advanced theoretical and clinical skills in a particular field, or branch, of physiotherapy, concluding in certification as a clinical specialist in that field. The strongest advocates of this type of post-registration certification are those private practitioners whose interests lie in orthopaedic manipulative therapy. Post-graduate degree education, on the other hand, concentrates on academic enrichment and/or original research.

Whether we have made the correct decision or not, the specialisation process seems well on its way to becoming a reality, having been approved in principle by the 1987 Council Meeting of the South African Society of Physiotherapy, and its proposed structure and functioning subsequently having been approved by the 1989 Council Meeting. An Interim College Council has been appointed, the Memorandum, Articles of Association and By-laws have been finalised, the basic structure, stages and standards for the process have been defined and Interim Speciality Boards have been set up in four speciality areas in order to develop the detailed criteria. The specialty areas already identified are cardiopulmonary, obstetrics and gynaecology, orthopaedic manipulative therapy and neuro-developmental physiotherapy - although these may not be the final designations. A call for nominations for Founders of the College of Physiotherapists of South Africa has already been published and the Inaugural Meeting of the College Council will be held in April 1991. The requirements for the specialisation process are not the subject of this article, but it is almost certain that the College will be operative from 1992

The specialisation process may satisfy the aspirations of a certain percentage of physiotherapists, but what of those interested in research and academic post-graduate study? To what extent are their needs being met? It is known that there are still very few post-graduate students and even fewer who have been successful; the drop-out rate is quite high. In order toassess the present situation the eight universities which offer undergraduate physiotherapy training were surveyed in 1989. Replies were received from all eight.

\section{RESULTS}

Because it was thought that some universities might be in the position of having to accept post-graduate students before the majority of their faculty members had themselves experienced postgraduate study, the academic credentials of faculty members were requested. The results are shown in Table 3.

\section{TABLE 3: ACADEMIC CREDENTLALS OF FACULTY MEMBERS (1989)}

Number of universities

Total number of posts (full-time equivalent)

Doctorates

Master degrees

Honours degrees

\section{TABLE 4: HONOURS DEGREE COURSE REQUIREMENTS}

\begin{tabular}{|c|c|c|c|c|}
\hline UNMERSITY & $A^{*}$ & E & $\mathbf{F}$ & $\mathbf{G}$ \\
\hline $\begin{array}{l}\text { Coursework only } \\
\text { Coursework and minithesis }\end{array}$ & $\begin{array}{l}\text { No } \\
\text { Yes }\end{array}$ & $\begin{array}{l}\text { No } \\
\text { Yes }\end{array}$ & $\begin{array}{l}\text { No } \\
\text { Yes }\end{array}$ & $\begin{array}{l}\text { Yes } \\
\text { No }\end{array}$ \\
\hline Minimum no. courses & - & 5 & 4 & 5 \\
\hline Average hours/course & - & 5 & 55 & $?$ \\
\hline Formal modules & - & $\mathbf{0}$ & 3 out of 4 & 1 out of 5 \\
\hline Compulsory subjects & - & 4 & 3. & 1 \\
\hline Minimum no. options & - & 1 out of 3 & 1 out of 4 & 4 out of? \\
\hline Assignments/course & - & 3 & 4 & 5 \\
\hline Tests/course & - & $\mathbf{0}$ & 2 & 1 \\
\hline Clinical component & Yes & No & Yes & No \\
\hline Yearmark specified & - & No & Yes & No \\
\hline Formal examinations & - & No & Yes & Yes \\
\hline - theory & - & - & 3 & $?$ \\
\hline - clinical & - & - & 3 & $?$ \\
\hline YM : EM & - & $\mathbf{N} / \mathbf{A}$ & $50: 50$ & $60: 40$ \\
\hline Subminimum EM & - & - & 60 & - \\
\hline Pass & 50 & 50 & 60 & 50 \\
\hline Cium laude & 75 & 75 & 70 & \\
\hline
\end{tabular}

Honours and masters programmes are analysed separately. Four of the eight universities offer courses at honours level. The course requirements are summarised in Table 4. It is obvious that requirements very considerably. One university offers no formal coursework, requires no tests or yearmark, and the outcome depends upon the quality of the seminars submitted by the student and her ability to discuss them. That particular university also has no clinical component. The remaining three universities all offer some formal courses or modules, although not necessarity in all subjects. 
These three universities all require some compulsory subjects (varying from one to four in number) plus one or more options. In general, the options depend upon the specific direction of study but one university offers, instead, several options in general physiotherapy subjects of which four must be completed. This university prescribes coursework only, whereas the remaining two universities combine coursework with mini-dissertations or seminars. Only one university lays down specific requirements for the derivation of year and examination marks. The same university has a higher pass-mark than the rest, requiring a minimum of $60 \%$ in the examination regardless of the yearmark.

Seven of the eight universities offer a masters degree by dissertation only. All require at least one external examiner. Three universities require oral defence of the dissertation (which in one case may be waived) and five do not. Again, one university requires a passmark of $60 \%$, the rest require $50 \%$. There is no reason to doubt the standard of these degrees and they are suited to those physiotherapists who have the desire and the ability to pursue independent research. Very few have been awarded so far.

\section{TABLE 5: MASTERS DEGREE COURSES}

\begin{tabular}{lccc} 
Coursework + dissertation & $D^{*}$ & $F$ & $H$ \\
\hline & & & \\
Minimum number courses & - & 5 & 4 \\
Compulsory subjects & - & 4 & 3 \\
Minimum no. options & - & 1 out of 5 & 1 out of 4 \\
Attendance courses & - & - & 4 \\
Assignments/course & - & 4 & $?$ \\
Test/course & - & 2 & $?$ \\
Clinical component & $?$ & Yes & No \\
Yearmark specified & Varies & Yes & No \\
Formal examinations & Yes & Yes & Yes \\
- theory & Varies & 3 & 4 \\
- clinical & - & 3 & - \\
- dissertation + oral & $?$ & 1 & 1 \\
Weighting & - & $33: 33: 33$ & $?$ \\
YM : EM & $50: 50$ & $50: 50$ & N/A \\
Subminimum EM & 40 & 60 & 50 \\
Pass & 50 & 60 & 50 \\
Cum laude & 75 & 75 & 75
\end{tabular}

*Content by arrangement for each candidate

No universities offer a masters degree by course-work only. As shown in Table 5, requirements vary from university to university. Three universities offer combined coursework and dissertation; at one of these universities this is the required form for candidates who do not possess an honours degree. Only this university requires a clinical component, which is equated to the clinical component for the missing honours course.

\section{DISCUSSION}

As has been shown, there are considerable differences between universities in post-graduate course structure, content, and requirements for completion. What is being offered by the universities also does not, in most instances, conform to the perceived needs of physiotherapists as determined by the 1986 survey, and this no doubt contributes to the low participation in post-graduate programmes thus far. Two other reasons may be advanced. Firstly, early undergraduate courses did not include research methodology or student projects in their curriculum, and so did not prepare physiotherapists for research. This is particularly relevant at the five universities which do not require an honours degree prior to admission to a mastersby-dissertation programme (seven of the universities grant honours status to four-year undergraduate degrees). The result of this situation is reflected in the survey response which indicated a preference for structured coursework. A second reason may be that many faculty members are themselves not yet active in research and are unable to act as effective study promotors.

For comparison, input was requested and received from Curtin
University in Australia and from Dalhousie University in Canada. Details of courses offered show a more structured curriculum than is offered at most South African universities. Dalhousie's proposal for a masters degree by coursework plus dissertation closely resembles the equivalent programmes at the universities of Stellenbosch and the Witwatersrand, but with more compulsory physiotherapy courses such as measurement, biomechanics, analytical kinesiology, pathokinesiology, development, motor performance, learning and skill acquisition, and gait analysis. Curtin University offers three levels of post-graduate study, each being a prerequisite for the next, i.e. post-graduate diploma, masters and doctoral programmes. The masters degree is offered either by research dissertation or by coursework plus dissertation. The coursework option is available in ten different areas. Once again the courses are well-structured and defined in terms of hours per week and number of credits.

The most noticeable difference between these two overseas courses and courses in this country is the student intake. Dalhousie, which at that time had not instituted its programme, anticipated 6 full-time and 12-20 part-time students after three years. Curtin has a total graduate student enrolment of $120-130$, of whom about 25 are full-time and $20-30$ are in masters or doctoral programmes. Of the over $\mathbf{2 0}$ faculty members, three hold doctorates, eight masters degrees, and all but two of the remainder have post-graduate diplomas.

How can we improve upon the state of affairs in this country? Firstly by analysing the problems. From the results of the two surveys the following problems appear to contribute to the situation:

- insufficient preparation for research at undergraduate level

- lack of consensus on objectives for post-graduate study

- lack of consensus on competency profiles for post-graduate students

- lack of expertise in post-graduate teaching amongst faculty members

- limited manpower resources in university physiotherapy departments

- limited financial resources, particularly for research. How can we tackle these problems? I believe that the first one is in the process of being solved. At seven of the eight universities there is a research component built into the final year of study, and at least three universities are producing student projects of a high standard, several of which have been published. (The South African Society of Physiotherapy offers an annual award for the best published student research project.) Recent graduates should therefore have the skills and confidence to encourage them to enter post-graduate programmes. Secondly, by reaching consensus on the objectives of post-graduate study and the competencies expected of the postgraduate student. Although the results of the 1989 survey were sent to all the universities for comment, only two replies were. received, and those only made minor corrections to facts previously submitted. There are two existing bodies in this country which would be capable of setting objectives and competencies. One is the Educational SubCommittee of the Professional Board, on which all universities are represented. The other is the Education Committee of the South African Society of Physiotherapy, which is smaller, but bas a broader representation of physiotherapy interests. When the competencies for graduates of undergraduate courses were set, the initiative was taken by the Education Committee of the South African Society of Physiotherapy and later endorsed by the Board. It may be that this will be the best path to follow once more, if for no better reason than that the Education Committee is a smaller body which meets more frequently. If this path is followed, however, commitment by and input from all universities is essential. Although the universities are autonomous bodies and complete conformity in post-graduate course structure is neither expected nor desirable, the results of the surveys make it clear that there is room for improvement, both in meeting the needs of physiotherapists and in establishing standards of academic excellence, which must also conform to the accepted standard of post-graduate programmes as laid down by NATED. 


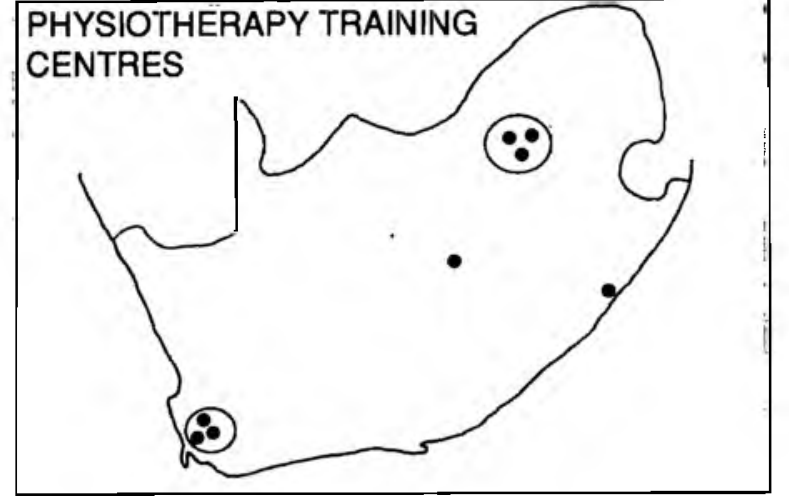

FIGURE 1: DISTRIBUTION OF CENTRES OFFERING POST-GRADUATE PHYSIOTHERAPY EDUCATION

The last three problems need to be tackled by optimum management and development of resources. Firstly - by utilising existing resources. The majority of physiotherapy training centres are clustered around two areas (Figure 1). Combining resources would result in more, experienced faculty members being available to more post-graduate students. The northern cluster would, at present, have at least eight faculty members with post-graduate degrees available as study leaders; the southern cluster would have at least five now and probably nine within the next year. The two outlying universities could enjoy a loose affiliation with the cluster of their choice, in their turn offering expertise in their own areas of special interest.

This interchange of expertise will not only be to the benefit of post-graduate education and research, but will also be instrumental in promoting interchange of ideas on physiotherapy and physiotherapy education in general, in developing theoretical concepts and in breaking through language and cultural barriers.

Not only human resources, but equipment resources need to be pooled. The cost of imported equipment is prohibitive and development programmes for locally designed and produced equipment are costly. Many universities have developed particular areas of interest and have purchased equipment relevant to those areas. Pooling equipment to develop, for example, one well-equipped exercise laboratory in each area makes sound economic sense as well as making more research equipment available to more post-graduate students and faculty members.

Lastly, we need to create new resources. One of the concepts particularly applicable to this country is that of distance education. Using this method, programmes or teaching modules developed in one centre can be disseminated to other centres, or even to individual students. There are many methods of distance teaching, ranging from a simple pack of printed material to highly sophisticated television programmes as used by the Open University in the United Kingdom. Canada and Australia make effective use of distance education. The South African Society of Physiotherapy is also in the process of developing distance teaching as part of a nation-wide quality assurance programme. This quality assurance programme is in two parts - a self-audit which will assess eight critical areas of patient care, and a series of self-instructional packages which will enable members or departments to update their knowledge and improve their performance in various clinical and non-clinical areas. These self-instructional packages will consist of a pre-test, a programmed instruction module incorporating written material and video or tape/slide presentation, and a self-evaluation (or post-test).

Distance education at post-graduate level requires rather more interaction between study leaders and students. One model used in Australia combines printed material, videos and audio-teleconferencing. Students receive reading matter (including objectives) two weeks before the telephone link-up. A videotape is viewed by the students as a group immediately prior to the link-up, which takes the form of a question and answer session. The students can review the video and, if necessary, study further printed material after the link-up. A self-assessment form is included in the learning package.

Most universities in this country have audio-teleconferencing facilities. If they do not, the Post Office can set up facilities for teleconferences on request. Several centres can be linked together, so that students at the outlying universities, and even all universities at once, can be involved. At each centre, several students and/or faculty members can take part, using a loud-speaker telephone (Figure 2).

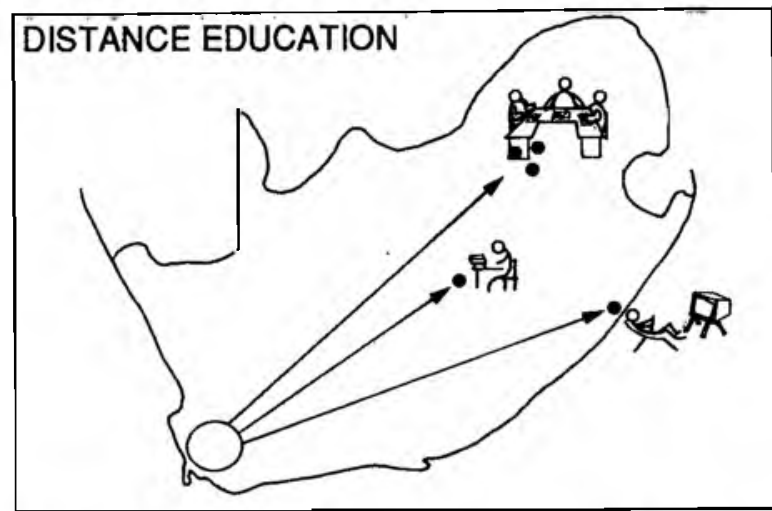

\section{FIGURE 2: POSSIBILTIES FOR DISTANCE TEACHING}

Another way of creating resources would be to establish a travelling fellowship, which would enable an expert from one university to present a particular module, or modules, at different universities around the country. This may sound expensive, but is considerably less so than creating an additional lecturing post at one university.

\section{CONCLUSION}

The need for post-graduate education has been establisted, but we need an in-depth look at post-graduate education programmes in order to establish objectives and competencies, as well as course structures which will satisfy the needs in this country. We need to differentiate between clinical specialisation - with its firstworld connotations - and academic post-graduate education and research which may equip today's graduate students to deal with tomorrow's complexity of health problems. Our only way of achieving this, within the bounds of the present economic standstill, is to pool existing resources and develop creative new ways of disseminating knowledge and expertise.

\section{ACKNOWLEDGEMENTS}

Grateful appreciation is recorded to Professor Joan Cole, of Curtin University, Perth, Australia, and to Professor Joan Walker of Dalhousie University, Halifax, Canada, for their willingness to share their experiences in post-graduate education, and to Edith McPhee, Education officer of the Australian Physiotherapy Association, for information on the use of distance education in Australia.

\section{REFERENCES}

1. Irwin-Carruthers S H. Physiotherapy practice in South Africa - yesterday, today and tomorrow. Physiotherapy Practice 1988 4: 207-212.

2. Cole J. Specialisation: a new reality for members of the Australian Physiotherapy Association. Australian Joumal of Phoviotherapy 1983; 29. 144-147.

3. Van de Meene LW. Towards the effective use of the specialist physiotherapist. Australian Joumal of Physiotherapy 1988; 34: 83-87.

4. Gilder JAC, Irwin-Carruthers SH, Kent A. Competency profile of the professional physiotherapist. Proc National Congress of the South African Society of Physiotherapy, Cape Town 1987; 188-192.

5. Hubbard DM. et al. Post-graduate medical education by distance learning. Audiovis Media Med 1986 9.69-73. 